\title{
Evaluating the risk of non-point source pollution from biosolids: integrated modelling of nutrient losses at field and catchment scales
}

\author{
P.G. Whitehead ${ }^{1}$, A.L. Heathwaite ${ }^{2}$, N.J. Flynn ${ }^{1}$, A.J. Wade ${ }^{1}$ and P.F. Quinn ${ }^{3}$ \\ ${ }^{1}$ Aquatic Environments Research Centre, Department of Geography, University of Reading, Whiteknights, Reading, RG6 6AB, UK \\ ${ }^{2}$ Centre for Sustainable Water Management, Lancaster Environment Centre, Lancaster University, Lancaster LA1 4YQ, UK \\ ${ }^{3}$ Department of Civil Engineering, University of Newcastle, NewcastleUK \\ Email for corresponding author: p.g.whitehead@reading.ac.uk
}

\begin{abstract}
A semi-distributed model, INCA, has been developed to determine the fate and distribution of nutrients in terrestrial and aquatic systems. The model simulates nitrogen and phosphorus processes in soils, groundwaters and river systems and can be applied in a semi-distributed manner at a range of scales. In this study, the model has been applied at field to sub-catchment to whole catchment scale to evaluate the behaviour of biosolid-derived losses of $\mathrm{P}$ in agricultural systems. It is shown that process-based models such as INCA, applied at a wide range of scales, reproduce field and catchment behaviour satisfactorily. The INCA model can also be used to generate generic information for risk assessment. By adjusting three key variables: biosolid application rates, the hydrological connectivity of the catchment and the initial P-status of the soils within the model, a matrix of P loss rates can be generated to evaluate the behaviour of the model and, hence, of the catchment system. The results, which indicate the sensitivity of the catchment to flow paths, to application rates and to initial soil conditions, have been incorporated into a Nutrient Export Risk Matrix (NERM).
\end{abstract}

Keywords: modelling, water quality, biosolids, sludge, nitrogen, phosphorus, water quality, River Lee, River Thames, River Stort, nutrient risk model

\section{Introduction}

In much of the world, increased inputs to land of nitrogen (N) and phosphorus (P) in the form of fertilisers, manures and biosolids has generated agricultural runoffs so rich in nutrients that water quality problems in rivers, lakes and estuaries have resulted (Whitehead, 1990; Johnes and Heathwaite, 1997). Numerous site-specific field studies have quantified the potential export of nutrients in agricultural runoff. The outputs from such empirical work must be synthesised before it satisfies the needs of end-users such as government agencies (Defra, Environment Agency), farm advisors and conservation bodies. Such a synthesis will enable optimisation of the application of nutrient to minimise costs to producers as well as impacts on the environment. Models, based on expert knowledge, of export of diffuse pollutants from land can assist this process but they must be easy to use and apply. This paper describes work utilising process-based models to evaluate the environmental risk of nutrient loss from agricultural land receiving applications of biosolids.

The seriousness of water quality deterioration in consequence of the export of nutrients in agricultural runoff has been documented recently for the UK (Environment Agency, 2000). Elevated diffuse nutrient loads result from the shift towards specialised and intensive farming systems that import, in feed and inorganic and organic fertilisers, more nutrients than are exported in produce. Excessive field applications of organic manures, sewage sludge and other industrial biosolids may supply such large amounts of $\mathrm{N}$ and $\mathrm{P}$ that localised build-up of these nutrients occurs in the soils, surface waters and groundwaters. Moreover, the physical and chemical characteristics of organic manures 
and industrial biosolids may also vary; on occasion they may act as both a sink and source of $\mathrm{N}$ and $\mathrm{P}$. This will enhance the risk of eutrophication in sensitive areas through increased nitrogen and phosphorus concentrations in surface waters. In intensively cultivated areas, nitrate in groundwater increased by 1-2 $\mathrm{mg} \mathrm{l}^{-1}$ per year in the 1970s (Whitehead, 1990; Burt et al., 1993); indeed, the average nitrate concentration in European rivers at $4.5 \mathrm{mg} \mathrm{NO}_{3}-\mathrm{N} \mathrm{l}^{-1}$ compares with values of $0.25 \mathrm{mg} \mathrm{NO}_{3}-\mathrm{N} \mathrm{I}^{-1}$ outside Europe. Similar trends are recorded for $\mathrm{P}$, the UK balance sheet for which shows a net surplus of $c .10 \mathrm{~kg} \mathrm{P} \mathrm{ha}{ }^{-1} \mathrm{a}^{-1}$, largely as a consequence of changes in land management that have enhanced the potential for P transport (Heathwaite et al., 2000a). Hence, it is important to identify those areas where biosolid application and/or soil management pose the greatest risks of $\mathrm{N}$ and $\mathrm{P}$ transfer, depending on soil status, erosion risk, runoff risk, presence of under-drainage systems and proximity to a watercourse.

Research efforts dealing with diffuse pollution have commonly taken one of three routes: (i) small-scale process studies conducted at the lysimeter, field plot or small (up to $1 \mathrm{~km}^{2}$ ) catchment scale, (ii) physically-based process models and (iii) nationally derived export coefficient techniques which give a broad picture of $\mathrm{P}$ and $\mathrm{N}$ loss (Heathwaite, 2003). The three routes are sometimes, but rarely, interlinked. Field experimental research has made some inroads in understanding the mechanisms of nutrient transport from agricultural land to receiving waters. Such data are invaluable in elucidating the processes of nutrient cycling and identifying the potential for nutrient loss. However, the temporal and spatial complexity of diffuse catchment sources means it is difficult to see how end-users can develop sensitive mitigation strategies without recourse to predictive models (Heathwaite, 2003). The available research on diffuse nitrogen pollution, for example, highlights the need for an improvement in predictive capacity to test various proposals for changes to agricultural land use and fertiliser management.

It is widely recognised that environmental measurements cannot be scaled-up directly (Beven, 1989). The types of measurements taken at a point $\left(1 \mathrm{~m}^{2}\right)$, may differ radically from measurements made at the hillslope scale $(1 \mathrm{ha})$, in small catchments $\left(1 \mathrm{~km}^{2}\right)$ or in large catchments $\left(1000 \mathrm{~km}^{2}\right.$; Heathwaite, 2003). Scaling issues, therefore, present one of the major challenges in integrating field and modelling approaches to diffuse pollution research. However, increasingly environmental measurements are being made accurately at a range of scales and frequencies and these form the basis of a combined monitoring and modelling strategy for addressing scale issues. In principle, synchronous determinations of the water and nutrient fluxes made at the point, plot, hillslope, catchment and basin scales, offer the best hope of understanding scale dependent effects and determining modelling strategies appropriate to specific scales of application. It is exactly this sort of approach that is being followed for an EPSRC-funded research project: The Seal Project - Strategic Management of Non-Point Source Pollution from Sewage Sludge. This project combines process-driven field experimentation with spatially-sensitive predictive modelling (http://www.lec.lancs.ac.uk/cswm/ seal.htm)

Much biosolid to land research has been conducted at the plot scale (Smith and Bennett-Travers, 2001) but management decisions and advice by farm advisors and water utilities (e.g. ADAS, 2001) for the strategic application of sludge to agricultural land must be made at the catchment scale so ways must be found of scaling up to control for the effect of landscape heterogeneity on diffuse contaminant export. Many factors control the movement of nutrients following the application of biosolids to land. These include hydrological flow paths and flow rates, soil adsorption/ desorption processes, soil moisture, residence times, application rates, land use and nutrient transport mechanisms. Any model predicting the impacts of biosolids to land should contain all these factors. The quasi-physical INCA model (Whitehead et al., 1998a,b; Wade et al., $2002 a, b)$ is the only model available at present that represents these processes, dynamics and interactions adequately at the scale required for analysis of biosolid to land applications. The semi-distributed nature of INCA allows nutrient cycling and export from sludge-amended land to be investigated at a wide range of scales from plot or field, to small first order catchments, up to large complex catchments.

Guidance on application rates for organic manures (including sewage sludge) is provided in the Code of Practice for the Protection of Water (1993) and by ADAS (2001a,b). Currently, $50 \%$ of the biosolid produced in the UK is recycled to agricultural land (1 072000 tonnes of dry solids were produced between 1998 and 2000; Defra, 2002). Recycling of sewage sludge to agricultural land is seen by the government as the Best Practicable Environmental Option (BPEO) in most circumstances, and with the projected increase in sludge available to agricultural land in the near future it is necessary to consider the possibly detrimental effects on the quality of the surrounding water courses (Bolton et al., 2004). There is a need for guidance, and recommendations, on the responsible use of organic manures, sewage sludge and industrial biosolids in agriculture without posing an increased eutrophication threat to waters due to inappropriate excessive application of $\mathrm{N}$ and $\mathrm{P}$. The current decision support systems available to 
end-users to assess biosolids to land risk are wholly agronomic, for example, the ADAS Safe Sludge Matrix (SSM) and MANNER model (ADAS, 2001a, b). The SSM has only two criteria: crop uptake (potential contaminant end-point) and biosolid type (potential contaminant hazard). For biosolid-derived nutrients, it is suggested that as the receptors are water bodies then crop uptake is not a useful risk indicator. The work reported here has focused on deriving a more environmentally-sensitive risk tool for biosolid-derived pollutants, with initial findings for the development and application of INCA-P at the SEAL field experimental site and in the Stort Catchment that receives the nutrients from the biosolid applications.

\section{THE SEAL SITE AND CATCHMENTS}

The experimental site used in the SEAL project lies in the catchment of the River Stort which itself is a sub-catchment of the River Lee system (see Fig. 1). The River Lee rises from springs near Luton, south-east England, (National Grid
Reference TL 061 248) and flows south through Bedfordshire, Hertfordshire and Greater London to join the River Thames at Blackwall. The Lee catchment covers an area of $1420 \mathrm{~km}^{2}$ and has an annual rainfall of $637 \mathrm{~mm}$ and a population of approximately 2000000 . From its source to its confluence with the Thames, the River Lee is $85 \mathrm{~km}$ long, the last $9 \mathrm{~km}$ being tidal. Elevations range from $157 \mathrm{~m}$ in the north of the catchment to $10 \mathrm{~m}$ at the confluence with the River Thames. Land use within the catchment is split along a north south divide. The north of the catchment is predominately agricultural; tilled arable is the principal land use (particularly barley and wheat). The north-western edge of the catchment is within the Chilterns Area of Outstanding Natural Beauty (AONB). By contrast, the south is predominantly a mix of suburban development and continuous urban.

The Rivers Mimram, Beane and Rib, all of which are of 'good quality' (Snook and Whitehead, 2004), join the Lee at Hertford. Downstream, the main river converges with the River Ash and at Fields Weir with its main tributary, the
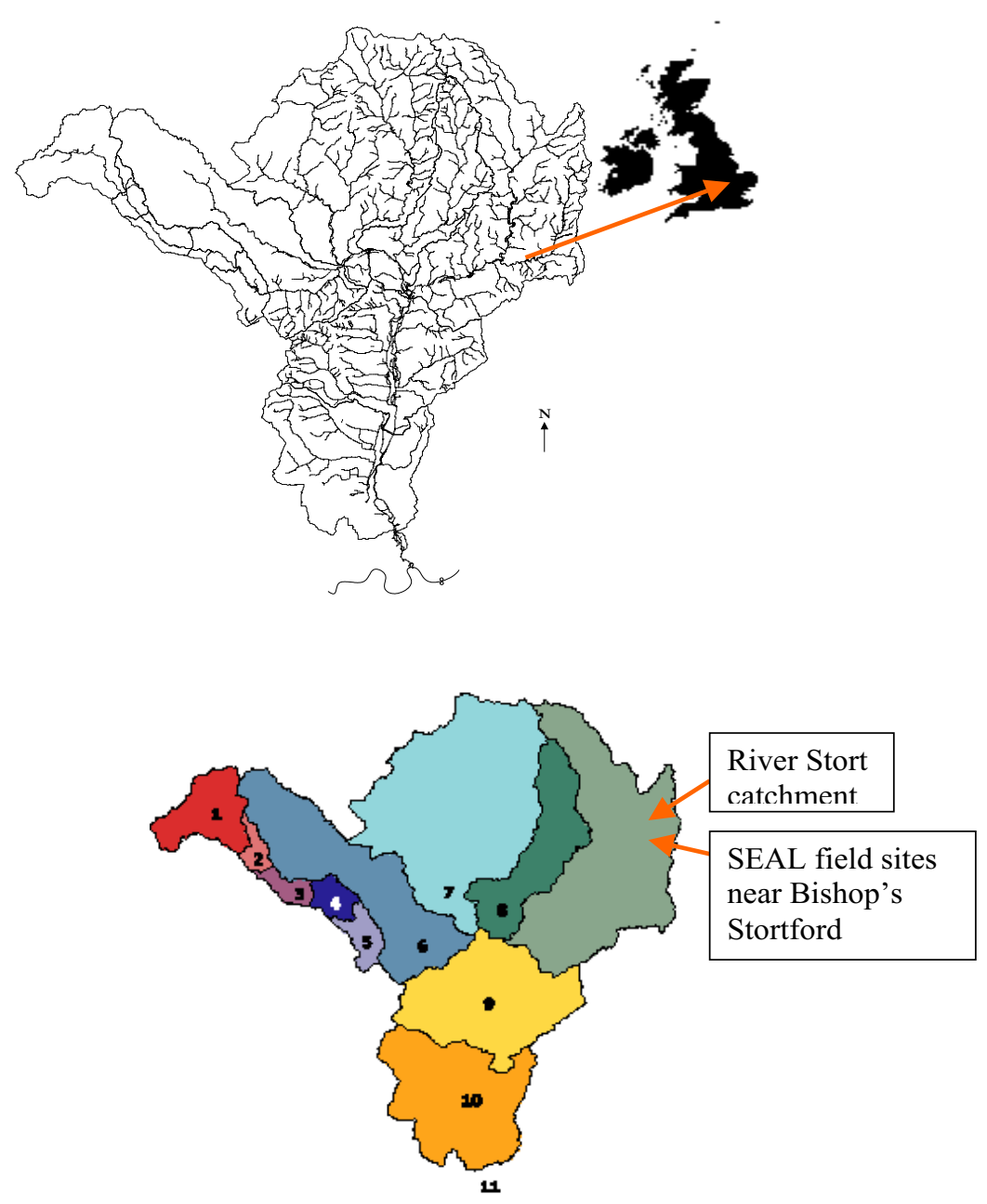

Fig. 1. The River Lee Catchment showing the river system network and the location of the Stort Catchment and the SEAL Field sites. 
Stort. Farther downstream still, Cobbins Brook, the Small River Lee, Pymmes Brook, Salmon Brook, the Old Moselle and Stonebridge Brook all join the Lee. Below Hertford the Lee Navigation canal begins and, in places, is the main channel or runs roughly parallel with the main channel, through urban London to its confluence with the Thames.

The solid geology in the north-west of the catchment is chalk, beyond a line between South Mimms to Stanstead St Margaret's. South-east of this line, the chalk is overlain by the Tertiary deposits of the London Basin, mainly London clay with some Woolwich and Reading Beds. This chalk aquifer has been an important source of London's water supply for many centuries. River, residual and glacial superficial deposits of Pleistocene to recent age mantle this solid geology. The river deposits range from alluvium to flood plain and terrace gravels. Residual deposits overlie the chalk, consisting principally of clay-with-flints. The glacial deposits are principally Boulder clay and glacial gravel. The River Lee and its tributaries generally flow over their own alluvium; watercourses are only occasionally in contact with the solid geology. The River Stort to the northeast of the Lee catchment has a catchment area of $281 \mathrm{~km}^{2}$. The Stort catchment geology is dominated by glacial sands and gravels which overlie the Upper chalk. The area has a gently undulating topography and the soils range from sandy loam to clay loam with boulder clay present in parts of the upper catchment.

The Lee catchment is covered by two Environment Agency Local Environment Agency Plans (LEAPS). The upper portion of the catchment, between its source at Luton and Fields Weir, is included in the Upper Lee LEAP, and includes the Rivers Mimram, Beane, Rib, Ash and Stort. Numerous urban areas fall within the upper catchment, including Luton, Dunstable, Stevenage, Welwyn Garden City, Hertford, Ware, Bishop's Stortford, Harlow and Sawbridgeworth. Downstream from Fields Weir, until its confluence with the Thames, the Lee catchment is covered by the North-London LEAP. The water quality and ecology of the River Lee is described in detail by Snook and Whitehead (2004).

\section{FIELD EXPERIMENTATION}

Figure 2 shows the Blackacre field site used for the experimental work undertaken for the EPSRC SEAL project near Stansted Mountfitchet, Essex, UK. The site is a 15.5 ha field at Bollington Hall Farm near Ugley in Essex (Grid Reference TL510 276 GB) which lies within the $26 \mathrm{~km}^{2}$ sub-catchment of the upper Stort. The field, known as Blackacre, is bounded on the south and west by farm roads, sloping down towards drainage ditches along the north and

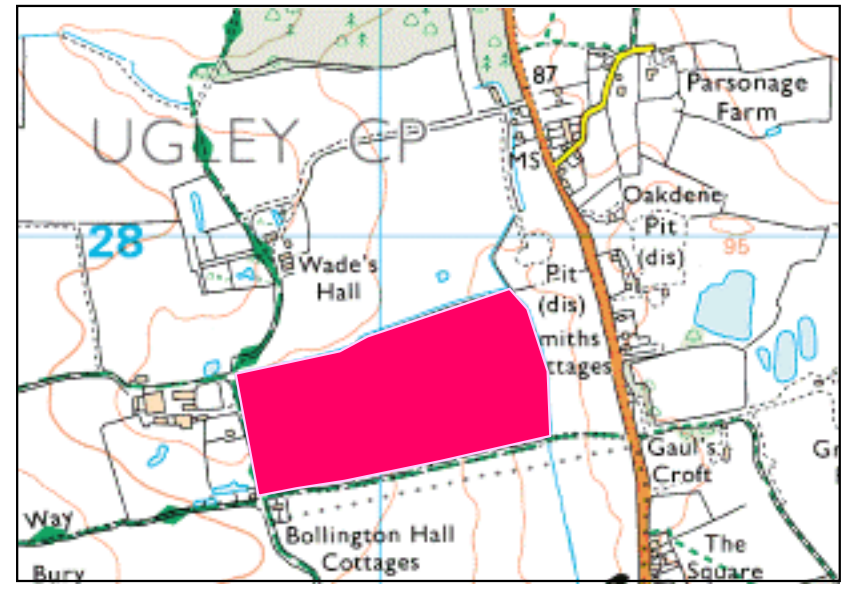

Fig. 2. Map showing location of Blackacre Field (highlighted), Bollington Hall Farm, Ugley, Essex

east boundaries. The soil in the field is predominantly clay but with some variety in the drainage characteristics and soil properties across the field. In fact the field can be subdivided into three areas by soil type, moving from heavy London clay at the western end of the field, through clay loam in the middle to sandy clay in the East. The site was chosen to investigate the environmental risk of nutrient transport to receiving waters from sludge applied on adjacent fields draining to the same stream system. Digested sludge cake and lime stabilised sludge were applied to the field site in September 2003 at a rate of 33 tonnes per hectare. The field site experimental set-up and the sampling techniques for monitoring the soils and waters are described in detail in Heathwaite et al. (2003b, 2005) together with the experimental results. The data have been used in the modelling studies to evaluate model performance.

\section{THE INCA MODEL}

The INCA model (Whitehead et al., 1998, 2002a,b) has been designed to investigate the fate of nutrients ( $\mathrm{N}$ and $\mathrm{P}$ ) in both aquatic and terrestrial environments. The model incorporates both dynamic and stochastic elements and is semi-distributed, with nitrogen $(\mathrm{N})$ and phosphorus $(\mathrm{P})$ fluxes produced as daily time series; outputs were assessed as either probabilistic or percentile values and spatial variations in land use categorised into land-use classes. The model has five main components: a GIS interface, a nitrogen input model, a hydrological model, a catchment nitrogen process model and a river nitrogen process model (Whitehead et al., 1998a). A semi-distributed GIS interface is used in INCA to represent percentage changes in landuse cover, together with a land classification scheme based on a simplified version of the Centre for Ecology and 
Hydrology (CEH) Land Cover Map of Great Britain, using six land classes as in Whitehead et al. (1998a). MORECS soil moisture and evaporation data are used to calculate daily Hydrologically Effective Rainfall (HER). Hydrology is simulated using a simple two-box model with soil- and ground-water components: each river reach is then modelled using a mass-balance approach to inputs, storage and outflow. Catchment nitrogen process mass balance differential equations in the soil- and ground-water are solved simultaneously with the equations of flow.

The INCA model has been applied to a variety of UK catchments, including the Rivers Tywi (Whitehead et al., 1998b), Dee (Wade et al., 2001b), Kennet (Whitehead et al., 2002b), Tweed (Jarvie et al., 2002) and Lee (Flynn et $a l .$, 2002). In Europe, the model has been applied extensively as documented in the Special Issue of Hydrology and Earth System Sciences dedicated to the INCA research (Wade and Neal, 2004). INCA was successful in reproducing patterns of nitrogen behaviour, accounting for changes in land use, hydrology and deposition, and providing a suitable modelling framework to investigate nitrogen dynamics in these catchments. The INCA model has been designed to investigate the fate and distribution of nitrogen in the aquatic and terrestrial environment. The dynamic nature of the model means that the day-to-day variations in flow $\mathrm{N}$ fluxes and concentrations can be investigated following a change in $\mathrm{N}$ inputs such as atmospheric deposition, sewage discharges or fertiliser application.

The phosphorus version of INCA (INCA-P) as described by Wade et al. (2002b) incorporates the same features as the nitrogen version of INCA. The model simulates subcatchments and main catchments on a semi-distributed basis and utilises a daily time step to generate daily time series of flow and total phosphorus. The key processes in the catchment include adsorption and desorption onto sediments, immobilisation of phosphorus into a non-soluble mineral form, uptake by plants and leaching from the catchment. As in INCA for nitrogen, all the processes are soil moisture and temperature dependent and the hydrology is driven by daily HER, temperature and soil moisture deficit. The instream component of the model simulates sedimentation, equilibrium with soluble phosphorus in the water column, macrophyte, epiphyte and phytoplankton growth. Velocity flow relationships are incorporated to allow calculations of residence time. The model also allows for sediment bed exchange of phosphorus with the water column. Graphical time series outputs are generated on a reach-by-reach basis or as a profile down the river system, together with all relevant statistics. The instream component of the model has been tested extensively against field data from the River Kennet system (Wade et al, 2001c, 2002a).

\section{APPLICATION OF INCA AT A RANGE OF SCALES}

Modelling always follows a considerable learning curve as calibration and validation of the model is undertaken at a range of scales. In the case of the SEAL project, the INCA model was applied initially at the whole catchment scale for flow, nitrate and ammonia and, then, the whole catchment phosphorus dynamics were investigated once field data for calibration became available. Having established the key process parameters at the large scale, the model was applied at the field scale to the Blackacre experiment. Finally, the model has been applied in a generalised manner to create risk assessment data for use in the NERM development.

The INCA-N model application to the River Stort involves setting up the key features of the catchment in the model. As shown in Table 1, the Stort has been broken down into eight reaches and adjacent sub-catchments, each of which has a land use determined from the $\mathrm{CEH}$ land classification system. In the case of the Stort, the land use is primarily agricultural and is dominated by cereal production. The daily patterns of rainfall, temperature and soil moisture deficit are crucial variables that control hydrology and the chemical

Table 1. Reach characteristics and land-use for the River Stort

\begin{tabular}{lcccccc}
\hline Reach & $\begin{array}{l}\text { Length }(\mathrm{m}) \\
(\mathrm{m})\end{array}$ & $\begin{array}{c}\text { Area } \\
\left(\mathrm{km}^{2}\right)\end{array}$ & Grassland & Cereal & Woodland & Urban \\
\hline Poor Bridge & 12000 & 26 & 0 & 100 & 0 & 0 \\
Manunden & 2500 & 17 & 0 & 100 & 0 & 0 \\
Gypsy Lane & 2000 & 32 & 13 & 84 & 0 & 3 \\
Cannons Mill & 1000 & 2 & 0 & 100 & 0 & 0 \\
Twyford Mill & 2000 & 22 & 5 & 82 & 0 & 14 \\
Sawbridgeworth & 2500 & 40 & 13 & 78 & 5 & 5 \\
Burnt Milll & 3750 & 98 & 5 & 89 & 0 & 6 \\
Glen Faba & 3250 & 44 & 35 & 45 & 5 & 15 \\
\hline
\end{tabular}


response of catchments. Figure 3 shows the time series of these for the River Stort over 1998/1999. The HER and the SMD have been obtained using the MORECS system and indicate the significant seasonality introduced by climate conditions over the year. The residence times in the model are 2.3 days for the soils and 56 days for the groundwater system; this reflects the dominance of the chalk geology in controlling the stream response. These values have been determined by trial and error to give the best fit to the hydrograph. Effluent discharges are also built into the model application so that point sources contribute to the nutrient mass balance. The effluent loads entering the River Stort from major discharges at Bishop's Stortford, Manunden and Standstead Mountfitchet account for $46 \mathrm{~kg}$ per day of phosphorus and $165 \mathrm{~kg}$ per day of nitrate; these comprise $41 \%$ of the total phosphorus in the river and $20.3 \%$ of nitrate (Snook and Whitehead, 2004). Thus the point sources in the lower reaches of the Stort contribute significant loads. Nutrient sources from the atmosphere and from animal husbandry are incorporated into the model using outputs from the Mattador-N model (Whitehead et al., 1998) for $\mathrm{N}$ deposition and the MAFF (2004) agricultural census data for cattle, sheep, pigs and poultry.

The INCA model results for flow, nitrate and ammonia are shown in Figs. 4 and 5 for the Twyford Mill and the Glen Faba reaches in the Stort. The simulation of flows in the Stort (Fig. 5) compares well with the observed flows and is a good match to storm events and the recession part of the hydrograph. Figure 4 shows the nitrate varying seasonally in the Stort as in most UK river systems, such as the Lee (Flynn et al., 2002). As in the Lee, nitrate concentrations are high, and Fig. 6 shows that the 95 percentile level is at the EU limits of $11.3 \mathrm{mg} \mathrm{l}^{-1}$. Thus, the application of INCA-N to the Stort gives considerable confidence that the hydrology and $\mathrm{N}$ dynamics are simulated correctly for the river system.

The simulation of flow and phosphorus using INCA-P follows from the $\mathrm{N}$ application, in that all the reach characteristics have been kept the same. Figure 7 shows the phosphorus version of the model for the years 1995-1996; these were particularly dry years and, as in the case of INCA$\mathrm{N}$, the phosphorus model gives an excellent simulation of

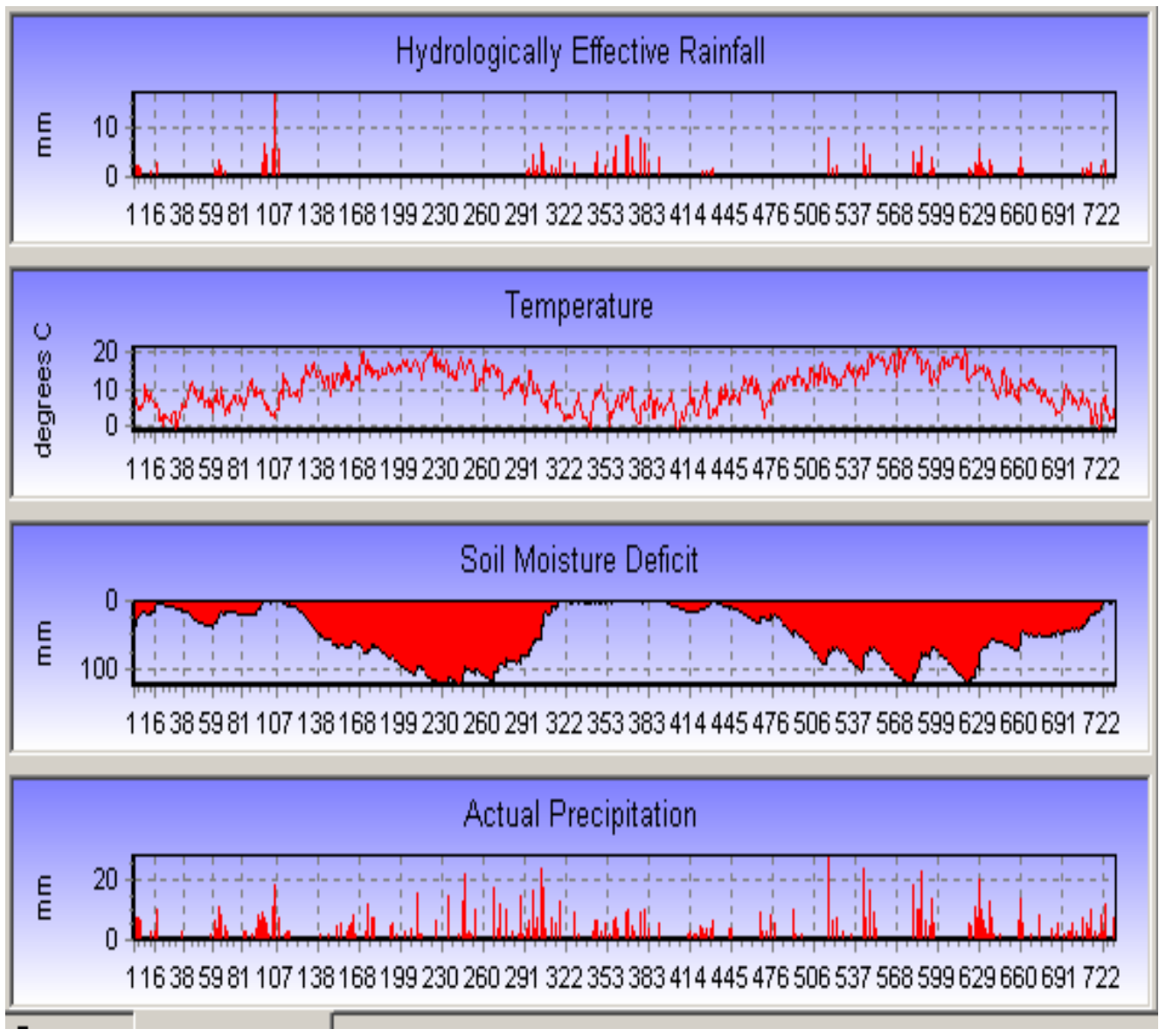

Fig. 3. Input daily times series for the River Stort for the year 1998 and 1999 


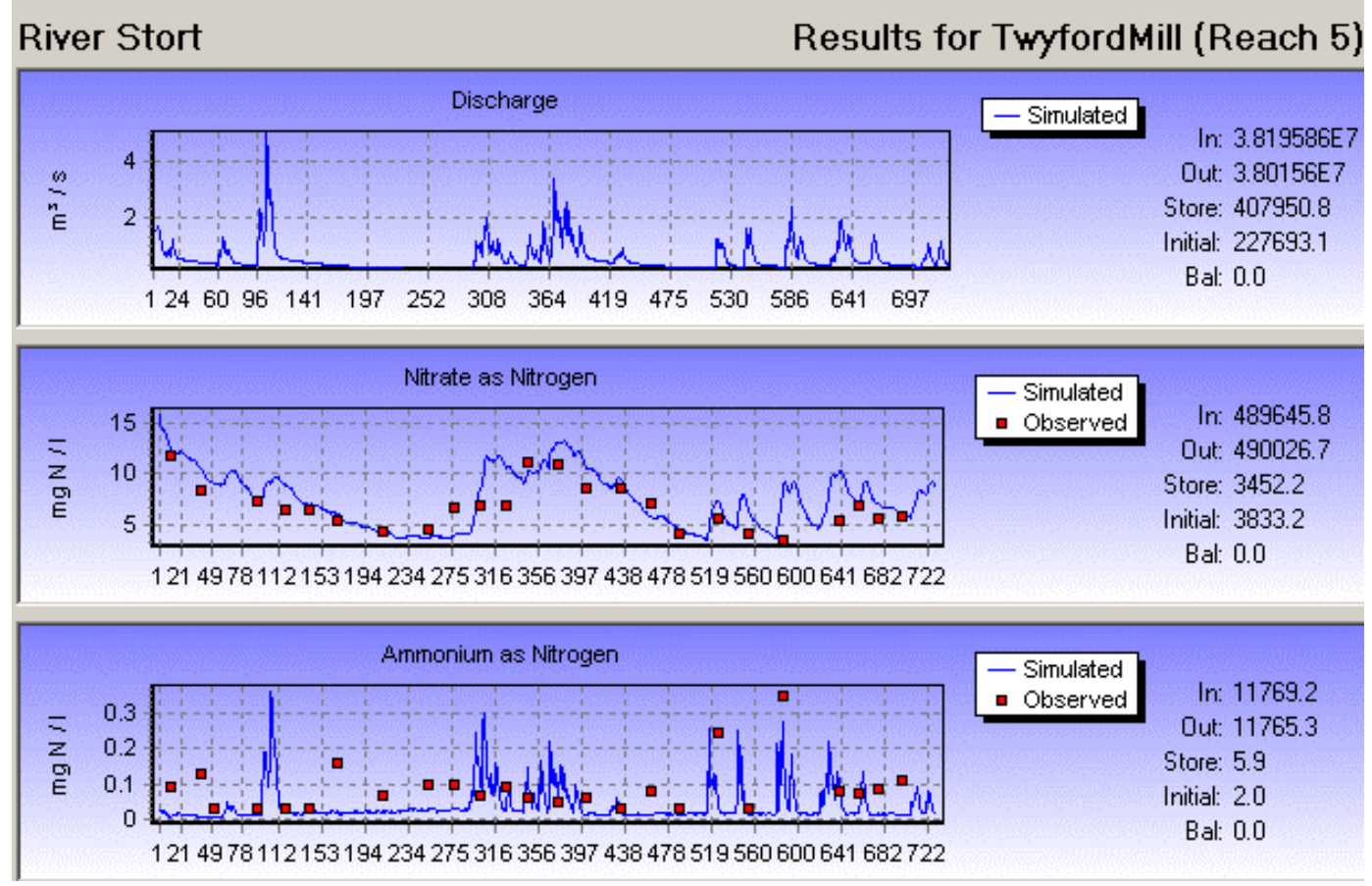

Fig. 4. Simulated and observed Flow, nitrate-N and ammonium- $N$ at Twyford Mill on the Stort

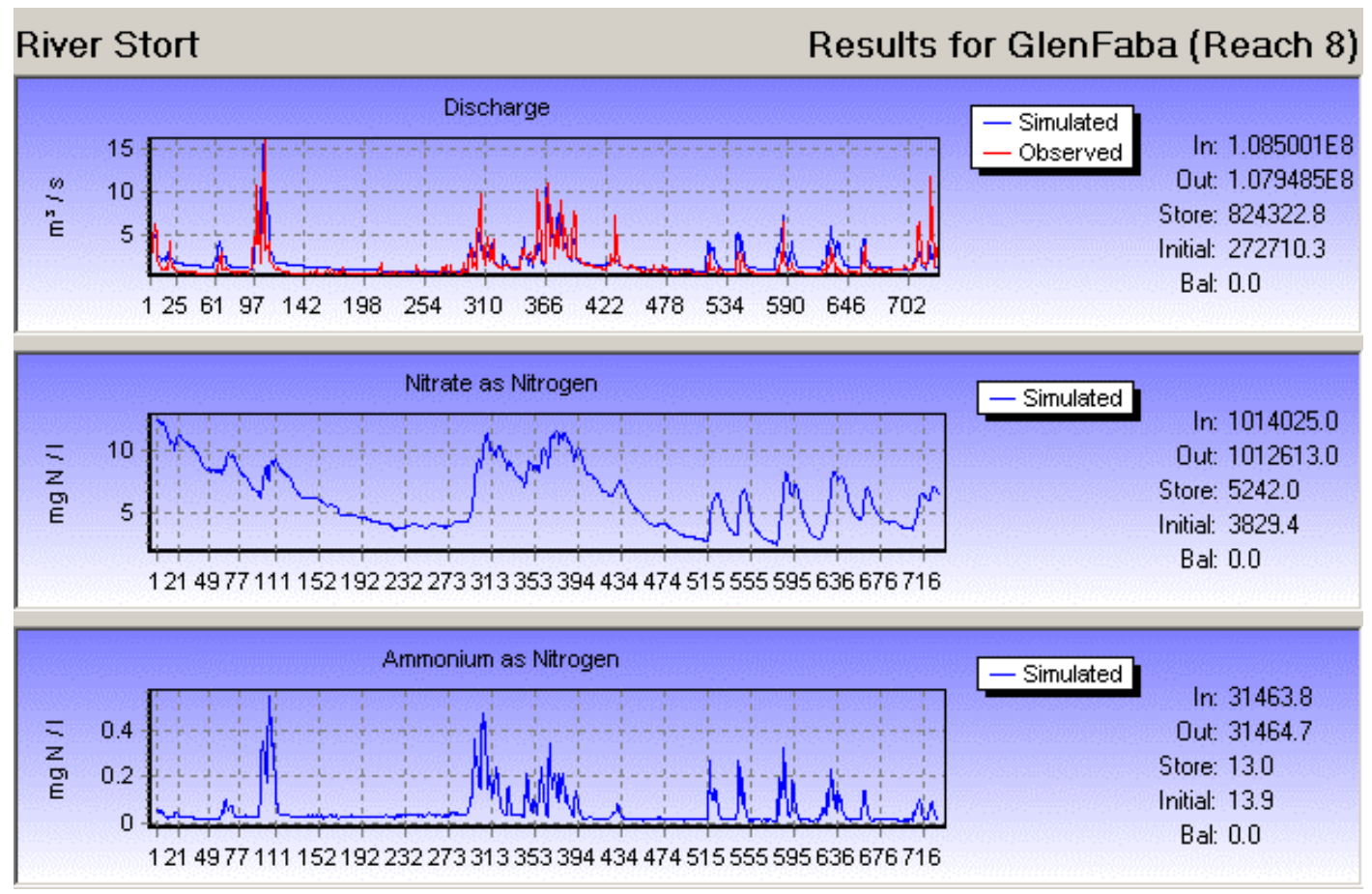

Fig. 5. Simulated and observed flow, nitrate- $N$ and ammonium- $N$ at Glen Faba on the Stort

flow and SRP at three reaches down the Stort, at Poor Bridge, Twyford Mill and Glen Faba, respectively. The observed SRP data are the routine sampling and measurements taken by the Environment Agency. The pattern of phosphorus concentrations in the river changes from the top reach to the lower reaches. In the upper reach, there are no effluent discharges and the SRP reflects the diffuse inputs from agricultural sources, with relatively low concentrations 


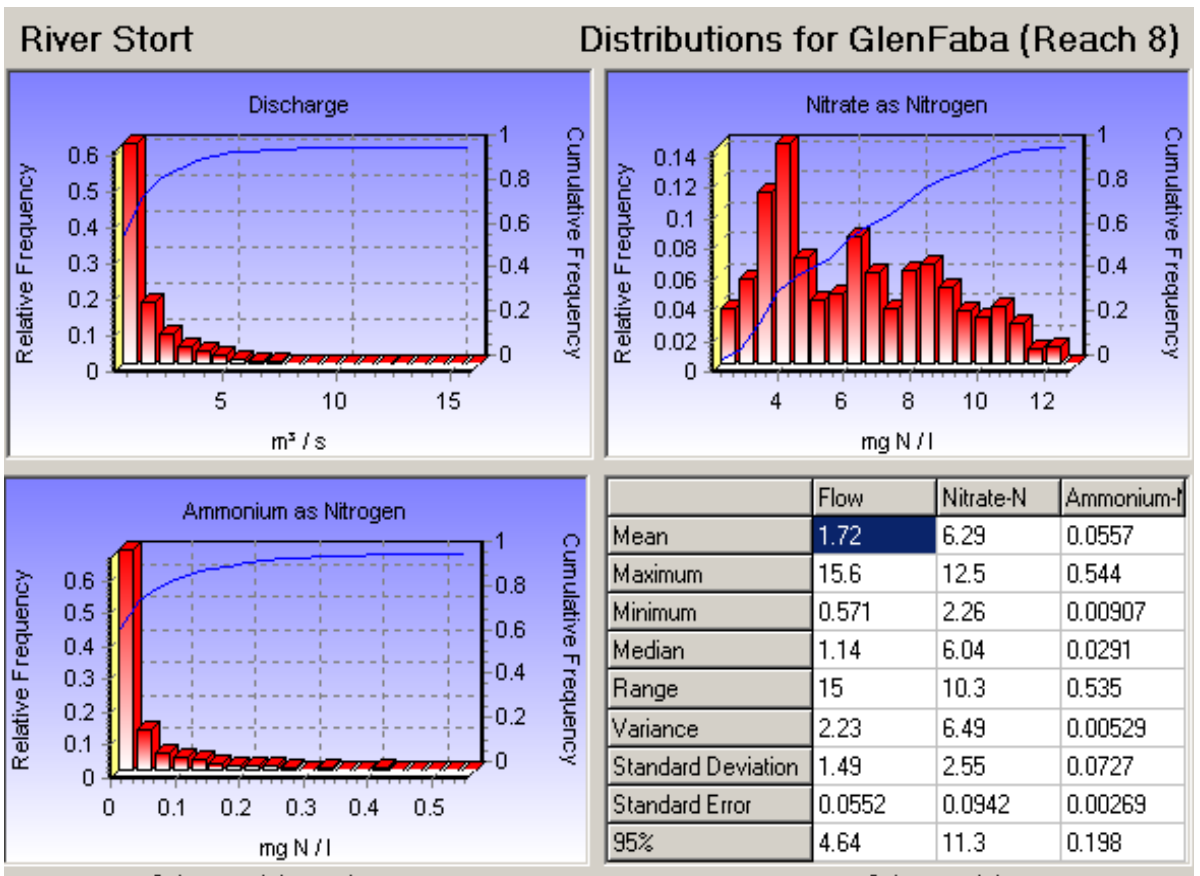

Fig. 6. Distributions of flow, nitrate and ammonium at Glen Faba on the Stort
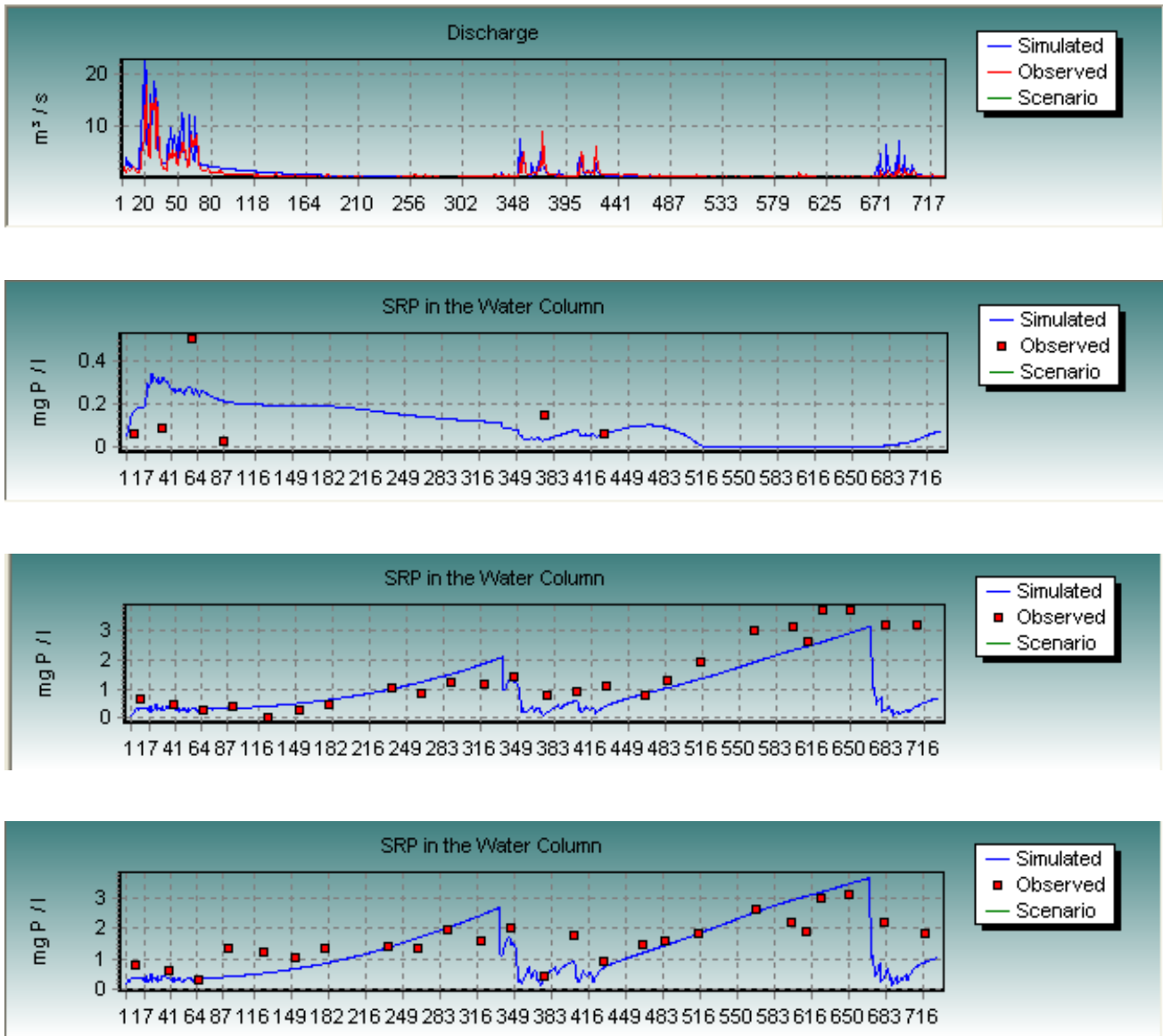

Fig. 7. Observed and simulated response over 1995-1996 for the River Stort at Glen Faba for flow and Poor Bridge, Twyford Mill, Glen Faba for SRP - observed data in red 
throughout the year and no major seasonal pattern. Unfortunately, no Total $\mathrm{P}$ data are available from the EA programme of monitoring. At the lower reaches, however, the SRP levels increase significantly under low flow conditions, because the dilution of the point source effluents entering the river declines with the flows over the summer months. This result is significant as it suggests that, in the Stort, the phosphorus concentrations in the river are dominated by sewage discharges rather than by diffuse runoff in all reaches except for the uppermost reach where there are no major effluent discharges.

Finally, the model has been applied to the Blackacre experimental site. The model has been set up using all the same process parameters as in the river application. However, a single reach of $500 \mathrm{~m}$ represents the ditch and $3.5 \mathrm{~km}^{2}$ is the total area draining into the ditch at Blackacre. Figure 8 shows the simulation results for flow and phosphorus for the 90-day period from December 2004. The observations in red confirm that a good simulation result has been obtained although the exact timing of the flow is slightly askew. This is to be expected because INCA is a daily simulation model and the storm response of the catchment is in the order of hours. However, the phosphorus results are very encouraging; even at this small scale, the model reproduces $\mathrm{P}$ transport from the land to the stream. Figure 9 shows an added scenario assuming that an additional biosolid loading of $10 \mathrm{~kg} \mathrm{ha}^{-1}$ is applied to the sub-catchment. The simulation shows a small but ecologically significant rise in the $\mathrm{P}$ concentrations in the stream, both in the water column and in the stream bed. The stream bed may be acting as a store in this situation, providing a pool of phosphorus for later transport down the system.

The successful application of INCA at a range of scales indicates that the model has considerable utility and could be used to assist in the impact assessment of biosolids on agricultural systems.

\section{PROCESS MODELLING AND THE NERM}

The INCA process-based model is essentially an 'expert system' that encapsulates a wealth of knowledge on hydrology, chemistry and ecology in both the terrestrial and aquatic environments. Hence, it provides an ideal tool for testing hypotheses about the mechanisms controlling nutrient transport at a range of scales. Most importantly, it can provide generic information on fluxes and can be used to inform the Nutrient Export Risk Matrix (Heathwaite et al., 2003a; Hewett et al., 2004; Burke et al., 2003). The field research carried out so far suggests that where agricultural land is subjected to nutrient loadings for agricultural benefit this may not lead immediately to a problem unless the nutrient is in a form to be transported and connectivity exists to a receptor. Figure 10 shows the

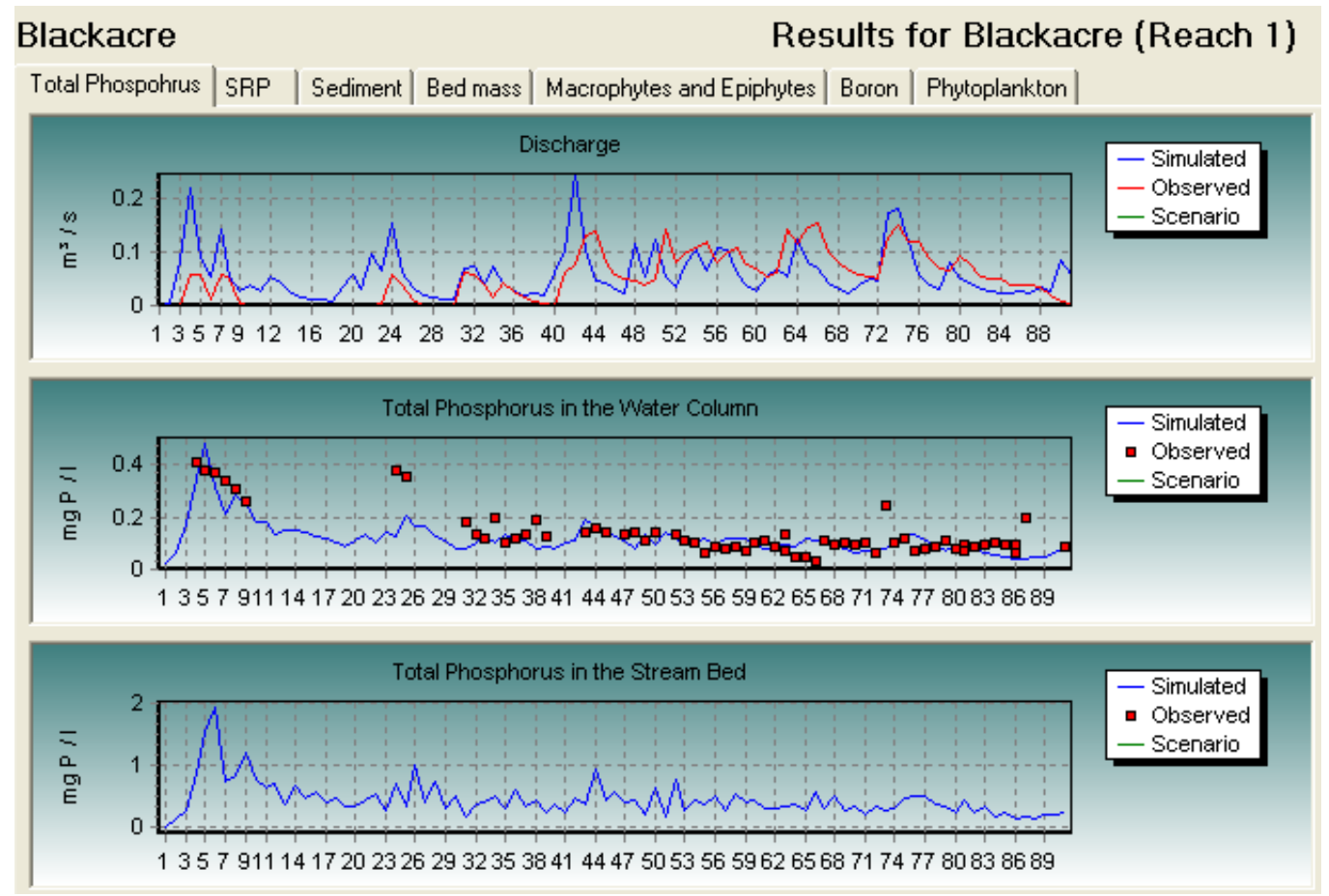

Fig. 8. Simulation of flow SRP and total P for the Blackacre field site over 90 days from $20^{\text {th }}$ November 2003 


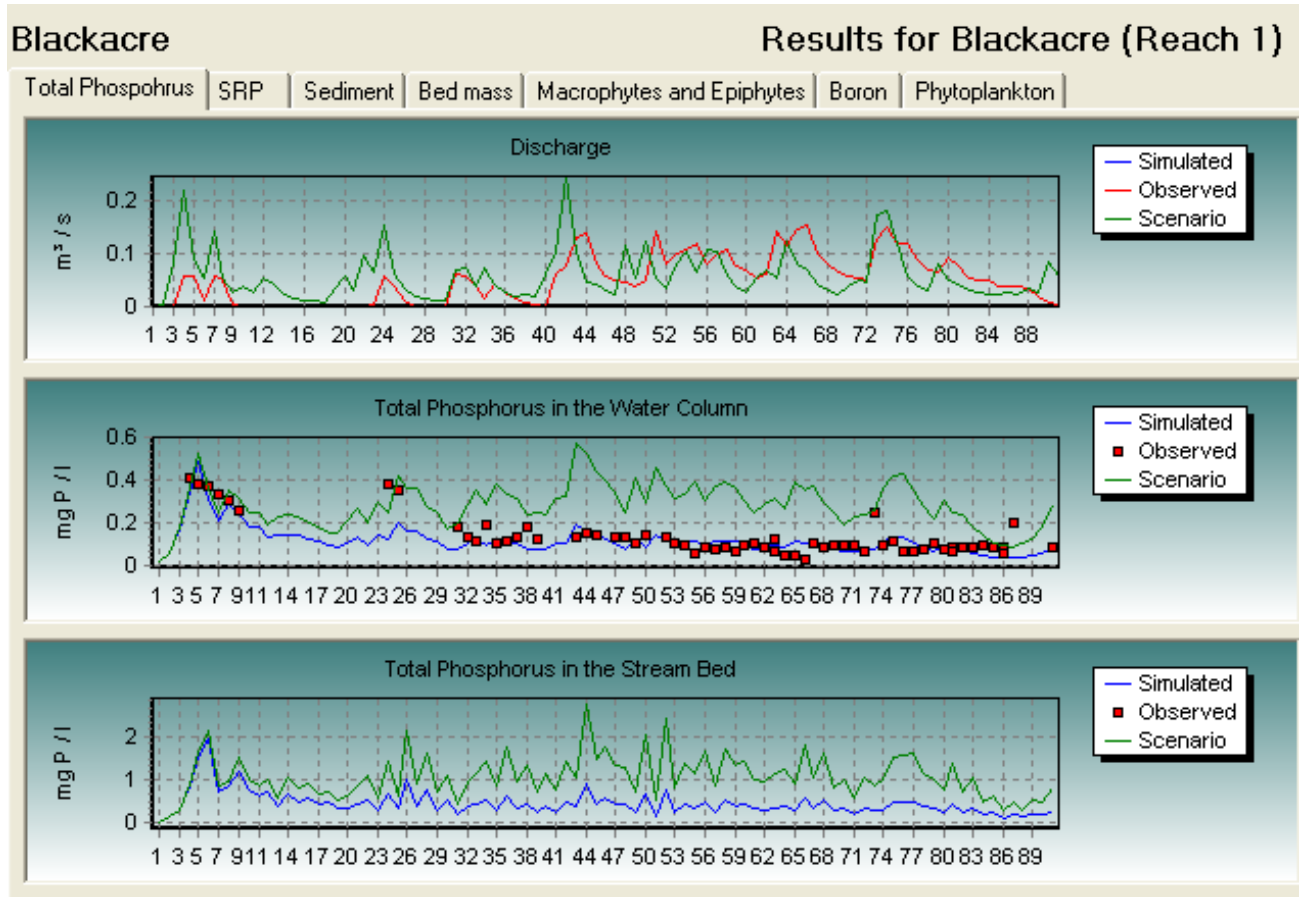

Fig. 9. Simulation of flow SRP and total P for the Blackacre field site over 90 days from $20^{\text {th }}$ November 2003 assuming an additional application of biosolid.

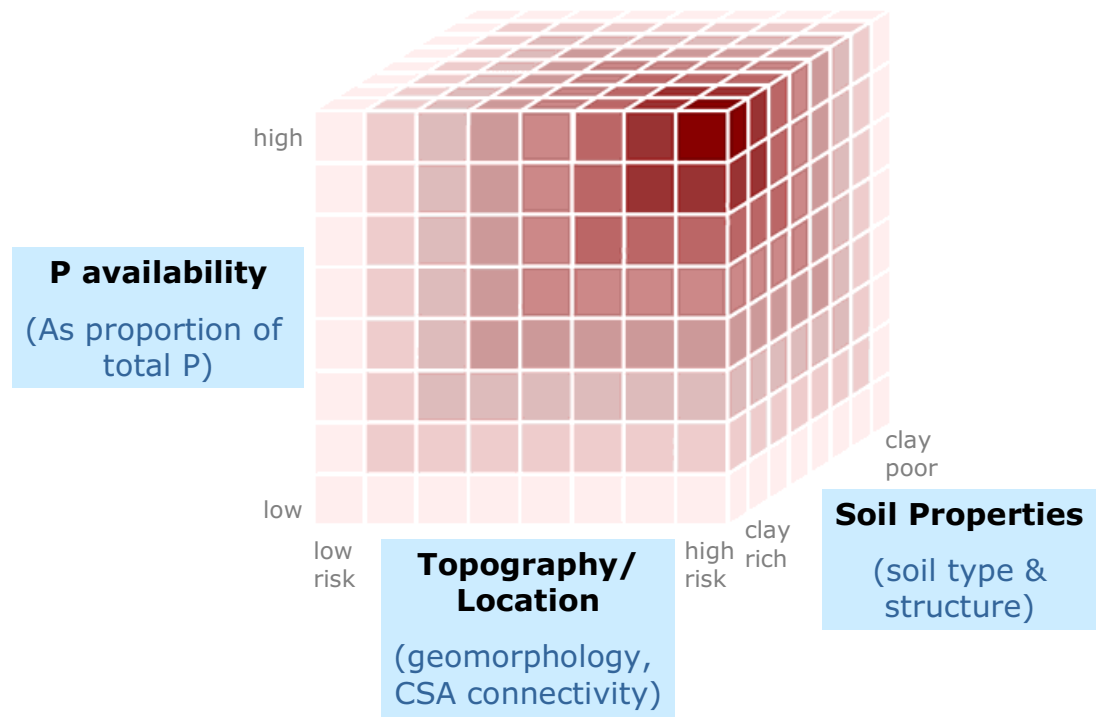

Fig. 10. The Nutrient Export Risk Matrix - the NERM - used to evaluate the availability of P from agricultural land to water according to the 2 key indicators of nutrient loss, namely soil properties and topography.

NERM (Nutrient Export Risk Matrix) that has been developed by the EPSRC SEAL project team as described in greater detail in Heathwaite et al. (2003). The NERM helps to identify where nutrient source areas and zones of high hydrological connectivity meet. The principles used to develop the NERM are embodied in the critical source areas (CSA) concept described by Heathwaite et al. (2005). The CSA concept is based on the principle that the contributing area for diffuse pollutants derived from agricultural sources depends on the coincidence of factors of source (soil, crop and management) and transport (runoff, erosion and channel processes) (Heathwaite et al., 2003b). 
The biochemical reactivity and mobility of different nutrients determines the spatial extent of this contributing area and the degree of environmental risk. For some elements, much of the water and nutrient runoff from catchments comes from relatively small areas and over relatively short time periods (e.g. Dillon and Molot, 1997; Pionke et al., 2000). The horizontal axes of the NERM describe the key factors thought to affect P delivery into streams, namely soil type and hydrological connectivity, whereas the vertical axis represents P availability or loss from the system.

In more detail, the vertical axis, which represents $\mathrm{P}$ availability (Fig. 5), is a synthesis of all possible forms of $\mathrm{P}$, integrating the effects of crop covers, tillage and husbandry regimes into a single estimate of how much of the $\mathrm{P}$ is actually available for direct mobilisation by overland, drain or subsurface flow. Even if a rough estimate is made, a comparative understanding of the surplus $\mathrm{P}$ in certain biosolid, FYM and bag fertiliser forms can be represented along with the total P loading of the field. This is essentially an estimate of the $\mathrm{P}$ surplus per unit area.

The horizontal axis Soil Type (Fig. 5) reflects the propensity of a certain soil, under certain cultivation, to lose $\mathrm{P}$ due to overland flow (attached to sediment as well as in soluble forms), to retain $\mathrm{P}$ or to lose $\mathrm{P}$ to sub-surface $\mathrm{P}$ (when the soil becomes P-saturated; Heathwaite and Dils, 2000). In this case, it allows a comparison of an estimate of the portion of flow that is lost to surface water with the loss to groundwater. The final axis, flow connectivity, assesses surface topography and the typical landscape features created by farmers, such as tyre tracks and land drains but also the potential benefits of environmental features such as buffer strips and wetlands. These aspects of $\mathrm{P}$ loss are difficult to assess accurately but semi-quantitative evidence can be accrued through a study of the terrain (especially if high resolution terrain maps are available). Thus, the NERM seeks to encapsulate a wide range of behaviour patterns in one expert system diagram.

To fill in parts of the NERM, use can be made of the INCA model to create generic results to inform the development of the NERM. This has been undertaken with the INCA-P version of the model to evaluate the effects of changing biosolid application rates, background soil $\mathrm{P}$ conditions and hydrological connectivity levels in the catchment. Runs with INCA have been undertaken varying these three driving variables and, in each case, the $\mathrm{P}$ export rates for the arable land-use component have been calculated. Figures 11, 12 and 13 show some of the results obtained from this analysis. Figure 11 shows how the $\mathrm{P}$ transport rates vary from 0 to $2.5 \mathrm{~kg} \mathrm{ha}^{-1} \mathrm{yr}$ as the rates of application of biosolids vary from 0 to $70 \mathrm{~kg} \mathrm{ha}^{-1} \mathrm{yr}$ and assuming high, medium and low

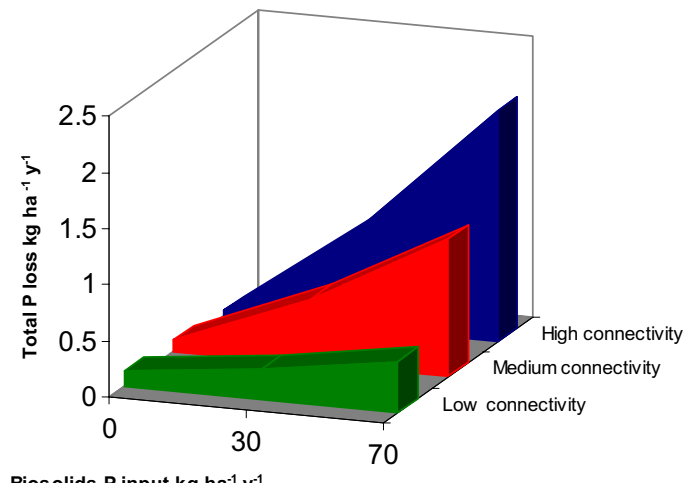

Bios olids $\mathrm{P}$ input $\mathrm{kg} \mathrm{ha}^{-1} \mathrm{y}^{-1}$

Low connectivity $\square$ Medium connectivity $\square$ High connectivity

Fig. 11. Predicted P loss assuming changes in biosolid application rates and hydrological connectivity

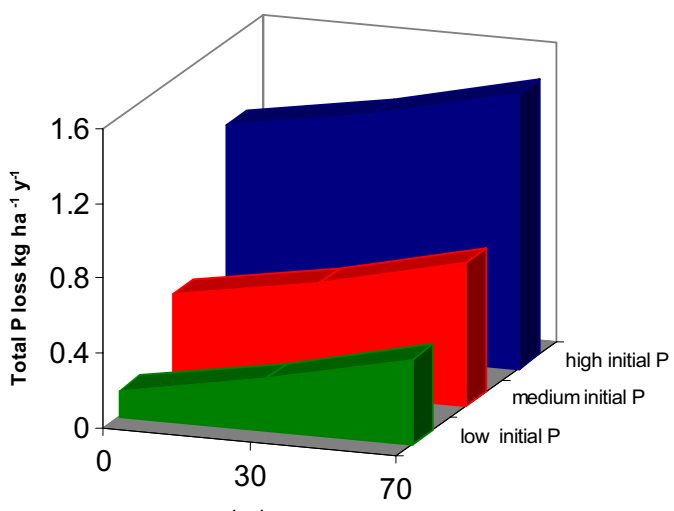

Biosolid $\mathrm{P}$ input $\mathrm{kg} \mathrm{ha}^{-1} \mathrm{y}^{-1}$

low initial $P \square$ medium initial $P \square$ high initial $P$

Fig. 12. P loss under conditions of low connectivity but with a range of initial soil $P$ conditions reflecting the history of $P$ applications in a catchment

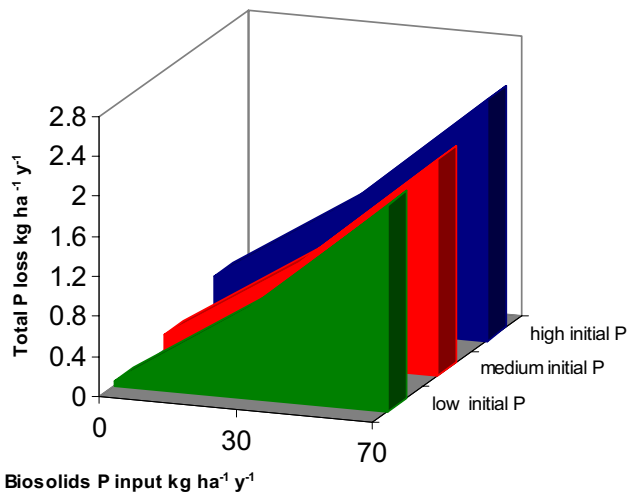

low initial $P \square$ medium initial $P \square$ high initial $P$

Fig. 13. P loss for a system that has high connectivity but with a range of initial soil $P$ conditions reflecting the history of $P$ applications in a catchment 
hydrological connectivity. The diagram shows that P export increases as application rates increase. However, the extent of P loss is highly dependent on connectivity so the highest loss rates are estimated by the model under the high connectivity condition, reflecting the rapid movement of water through the surface and soil horizons.

The effect of the groundwater store in the low connectivity runs is to reduce the $\mathrm{P}$ loss rate as $\mathrm{P}$ is retained in the groundwater system. The chalk sub-surface geology will bind the $\mathrm{P}$ to the calcium-rich matrix in the Stort catchment and, thereby, reduce P release to the river system. Figure 12 shows the results for $\mathrm{P}$ export under conditions of low connectivity but with a range of initial soil $\mathrm{P}$ conditions reflecting the history of $\mathrm{P}$ application in a catchment. With low connectivity (i.e. a groundwater dominated system) the response is damped with respect to biosolids application but the loss rate increases rapidly with soil $\mathrm{P}$ concentration. This suggests that agricultural areas that have a long history of $\mathrm{P}$ application and high initial $\mathrm{P}$ levels will lose considerable rates of $\mathrm{P}$ even in low connectivity areas. By contrast, Fig. 13 shows the $\mathrm{P}$ export for a system with high connectivity; here the loss rate is independent of the soil conditions as biosolid P loss will increase rapidly as biosolid applications increase.

\section{Conclusion and discussion}

The major problem in scaling up water quality models lies in the degree to which processes apply at a wide range of scales. The engineering literature shows that process equations can be scaled up and transferred from small pilot plant to large industrial scale systems, because the fundamental processes such as conservation of mass operate at all scales. This also applies in the natural environment and, therefore, scale-up should be possible. As in any scaleup situation, it is the dimensions that change and, therefore, the parameters in the equations have to be either dimensionless or scale independent. Thus, dimensionless groups such as the Reynolds number apply to the turbulence of streams and fluid flow, irrespective of scale. However, processes such as denitrification rates in streams have units of days/water depth reflecting the importance of both residence time and the shallowness of the water. Thus, scaleup is possible provided the basic units do not change. In the case of the INCA applications described in this paper, the time scale is maintained at a daily level and, hence, the time component of the parameters is not violated. However, this argument breaks down as the spatial scales become small. Thus, applying INCA to very small plots where the residence times are likely to be of the order of hours or minutes instead of days may produce misleading results.
There is also the issue of measurement and of the representativity of data at range of scales. Ideally, this should involve monitoring, using new approaches such as high frequency, multi-channel determination of streamwater chemistry using new measurement technologies and spectral analysis techniques. Although this is extremely expensive, it remains an exciting prospect for the future.

An important conclusion of the INCA application to the River Stort is the comparison of the effect of direct effluent discharges with those due to the diffuse sources. The concentrations in the river are almost dominated by the direct discharges with high concentrations in summer as flow rates fall and dilution of effluent is reduced. This has implications for management as it suggests that reducing phosphorus in the effluents will have a major beneficial effect in the lower reaches of the River Stort. However, the upper reach is affected by diffuse sources.

Ultimately, it is hoped to evaluate the role of spatiallydynamic runoff zones or critical source areas (CSAs) within model predictions by linking INCA together with complimentary field scale models developed under the EPSRC SEAL project using a smart export coefficient approach to derive fine-scale DEMs that predict CSA behaviours (Heathwaite et al., 2005) and a practical risk matrix approach described by Hewett et al. (2004).

\section{Acknowledgements}

This research was funded by EPSRC project number GR/ N26074/01, The SEAL Project: Strategic Management of Non-point Source Pollution from Sewage Sludge, awarded to the Universities of Sheffield (subsequently Lancaster University), Reading and Newcastle under the WITE (Water Infrastructure and Treatment Engineering Initiative).

\section{References}

ADAS, 2001. Managing Livestock Manures (MANNER), ADAS Gleadthorpe Report, Mansfield, UK.

ADAS, 2001. The Safe Sludge Matrix. ADAS Gleadthorpe Report. $4 \mathrm{pp}$.

Bolton, L., Heathwaite, A. L., Sinclair, H. and Burke, S.P., 2004. Strategic management of non-point source pollution from sewage sludge. In: Hydrology: Science and practice for the 21st century, Proc. British Hydrological Society Conference, Imperial College, London, 12-16 July, 365-370.

Burke, S.B., Heathwaite, A.L., Quinn, P. F., Merrett, S., Whitehead, P.G., Preedy, N.P., Lerner, D.L. and Saul, A.J., 2003. Strategic management of non-point source pollution from sewage sludge: the SEAL Project. Water Sci.Technol., 47, 305-310.

Burt, T.P., Heathwaite, A.L. and Trudgill, S.T., 1993. Nitrate: Processes, Patterns and Management. Wiley, New York, USA. $456 \mathrm{pp}$. 
Beven, K.J., 1989. Changing ideas in hydrology: the case for physically based models. J. Hydrol., 105, 157-172.

DEFRA, 1993. Code of Practice for Protection of Water, Agricultural Use of Sewage Sludge. DEFRA, London, UK.

Dillon, P.J. and Molot, L.A., 1997. Effect of landscape form on export of dissolved organic carbon, iron and phosphorus from forested stream catchments. Water Resour. Res., 33, 2591-2600.

Environment Agency, 2000. Aquatic eutrophication in England and Wales: a management strategy. National Centre for Ecotoxicology and Hazardous Substances, Wallingford, UK. $23 \mathrm{pp}$.

Flynn, N.J., Paddison, T. and Whitehead., P. G., 2002. INCA modelling of the Lee system: strategies for the reduction of nitrogen loads. Hydrol. Earth Syst. Sci., 6, 467-483.

Heathwaite, A.L., 2003. Making process-based knowledge useable at the operational level: a framework for modelling diffuse pollution from agricultural land. Environ. Model. Software, 18, 753-760.

Heathwaite, A.L. and Dils, R.M., 2000. Characterising phosphorus loss in surface and subsurface hydrological pathways. Sci. Total Envir., 251/252, 523-538.

Heathwaite, A.L., Sharpley, A.N. and Gburek, W.J., 2000. A conceptual approach for integrating phosphorus and nitrogen management at watershed scales. J. Environ. Qual., 29, 158166.

Heathwaite, A.L., Burke, S. and Quinn, P.F., 2003a. The nutrient export risk matrix (NERM) for strategic application of biosolids to agricultural land. IAHS Publication no. 285, 1-9.

Heathwaite, A.L., Sharpley, A.N. and Bechmann, M., 2003b. The conceptual basis for a decision support framework to assess the risk of phosphorus loss at the field scale across Europe. J. Plant Nutr. Soil Sci., 166, 1-12.

Heathwaite, A.L., Quinn, P. F. and Hewett, C.J.M., 2005. Modelling and managing critical source areas of diffuse pollution from agricultural land by simulating hillslope flow connectivity. J. Hydrol., 304, 446-461.

Hewett, C., Quinn, P.F., Whitehead, P.G., Heathwaite, A.L. and Flynn, N., 2004. A nutrient export risk matrix approach to managing agricultural pollution at source, Hydrol, Earth Syst. Sci., 8, 834-845.

Jarvie, H.P., Wade, A.J., Butterfield, D., Whitehead, P.G., Tindall, C.I., Virtue, W.A., Dryburgh, W. and McGraw, A., 2002. Modelling Nitrogen dynamics and distributions in the River Tweed, Scotland: an application of the INCA model. Hydrol. Earth Syst. Sci., 6, 433-453.

Johnes, P.J. and Heathwaite, A.L., 1997. Modelling the impact of land use change on water quality on agricultural catchments. Hydrol. Process., 11, 269-286.

Pionke, H.B., Gburek, W.J. and Sharpley, A.N., 2000. Critical source area controls on water quality in an agricultural watershed located in the Chesapeake Basin. Ecol. Eng., 14, 325-335.

Smith, S.R. and Bennett-Travers, D.M., 2001 Field trials to develop fertiliser advice for enhanced treated and conventional biosolids. In: Proc. CIWEM/Aqua Environ. Consultancy Services $6^{\text {th }}$ European Biosolids and Organic Residuals Conference. 12 14 November, Wakefield, UK.
Snook D. and Whitehead, P.G., 2004. A review of water quality and ecology of the River Lee. Hydrol. Earth Syst. Sci., 8, 636650

Wade, A.J. and C. Neal, (Eds.), 2004. Assessing nitrogen dynamics in European ecosystems: integrated measurement and modelling. Hydrol. Earth Syst. Sci., 8, 597-860.

Wade, A.J., Neal, C., Soulsby, C., Langan, S J. and Smart, R.P., 2001a. On modelling the effects of afforestation on acidification in heterogeneous catchments at different spatial and temporal scales. J. Hydrol., 250, 149-169.

Wade, A.J., Soulsby, C., Langan, S J., Whitehead, P.G., Edwards, A.C., Butterfield, D., Smart, R.P., Cook, Y. and Owen, R.P., 2001b. Modelling Instream Nitrogen variability on the Dee catchment, NE Scotland. Sci. Total Envir., 265, 229-252.

Wade, A.J., Hornberger, G.M., Whitehead, P.G., Jarvie, H.P. and Flynn, N., 2001c. On modelling the mechanisms that control instream phosphorus and macrophyte dynamics: an assessment of a new model using General Sensitivity Analysis. Water Resour. Res., 37, 2777-2792.

Wade, A.J., Durand, P., Beaujouan, V., Wessel, W.W., Raat, K.J., Whitehead, P.G., Butterfield, D., Rankinen, K. and Lepisto, A., 2002a. Towards a generic nitrogen model of European ecosystems: INCA, new model structure and equations. Hydrol. Earth Syst. Sci., 6, 559-582.

Wade, A.J., Whitehead, P.G. and Butterfield, D., 2002b. The Integrated Catchments model of Phosphorus dynamics (INCAP), a new approach for multiple source assessment in heterogeneous river systems: model structure and equations. Hydrol. Earth Syst. Sci., 6, 583-606.

Whitehead, P.G., 1990. Modelling nitrate from agriculture into public water supplies. Phil. Trans. Roy. Soc. Lond., B329, 403410 .

Whitehead, P.G., Wilson, E.J. and Butterfield, D., 1998a. A semidistributed integrated nitrogen model for multiple source assessment in catchments (INCA): Part I - model structure and process equations. Sci. Total Envir., 210/211, 547-558.

Whitehead, P.G., Wilson, E.J., Butterfield, D. and Seed, K., 1998b. A semi-distributed integrated nitrogen model for multiple source assessment in catchments (INCA): Part II- Application to large river basins in South Wales and Eastern England. Sci. Total Envir, 210/211, 559-583.

Whitehead, P.G., Johnes, P.J. and Butterfield, D., 2002 .Steady state and dynamic modelling of nitrogen in the River Kennet: impacts of land use change since the 1930s. Sci. Total Envir., 282/283, 417-435.

Whitehead, P.G., Lapworth, D.J., Skeffington, R.A. and Wade, A.J., 2002. Excess nitrogen leaching and $\mathrm{C} / \mathrm{N}$ decline in the Tillingbourne catchment, southern England. Hydrol. Earth Syst. Sci., 6, 455-466. 